\title{
Socio-cultural Issues of Allergens in Foods Served in School Canteens, in Prague, the Capital City of the Czech Republic
}

\author{
Marek Merhaut \\ Department of Marketing and Communication, Institute of Hospitality Management in Prague 8, Czech Republic
}

Copyright $(2016$ by authors, all rights reserved. Authors agree that this article remains permanently open access under the terms of the Creative Commons Attribution License 4.0 International License

\begin{abstract}
Allergies to a certain food are most likely to occur in children under six years of age; however, they can develop later, even into adulthood. Ironically, the most common allergens in older children and adults are the foods that we consider to be healthy or even necessary, such as nuts, cheese, fish, poppy seeds, or aromatic fruit and vegetables [1]. A food allergy is an oversensitive reaction by the organism to a food or foods, where the body may exhibit one or more symptoms from a relatively wide range of symptoms. It affects $2-3 \%$ of people, and in infants and children up to three years of age it affects upwards of 5-8\% (with some sources saying more than 10\%). Food allergies cause an adverse reaction to a food and involve a conditional response by the immune system. This definition is important because there is also the possibility of adverse reactions to foods that may be caused by something other than the immune system (e.g., lactose intolerance or irritation when digesting certain foods, such as coffee or ripened cheeses). An allergy is a hypersensitive reaction of the immune system to common substances, allergens, to which it often comes into contact. School canteens should strive to offer a varied and balanced diet, especially to our children, so that they get everything necessary to support their successful development and overall health. The composition of the menus should include the recommended amounts set to fulfill the daily requirement of essential nutrients. Activities of school canteens in the Czech Republic are governed by Act no. 561/2004 Coll., on preschool, primary, secondary, vocational and other training, in particular the provisions of $\S 119$, section 11 , with the relevant implementing rules and regulations [3].
\end{abstract}

Keywords Allergens, School Canteen, Food Allergy, Dietary Measures, Composition of Food

\section{Introduction}

The main objective of this empirical research is to analyze the level of awareness and information among the public (pupils in primary school, families, employees of school canteens) of the occurrence of allergens in foods that are offered in school canteens selected primary schools in the City of Prague. On December 13, 2014 European Parliament and Council Regulation (EU) no. 1169/2011 of 25 October 2011 on the provision of food information to consumers went into effect [5]. This regulation requires catering operations to inform consumers about allergens contained in the dishes offered (including drinks). School canteens must also accommodate this regulation and menus must feature a list of allergenic foods contained in the meal [6]. These are: Cereals containing gluten, namely: wheat (such as spelt and khorasan wheat), rye, barley, oats; Crustaceans for example prawns, crabs, lobster, crayfish; Eggs; Fish; Peanuts; Soybeans; Milk (including lactose); Nuts; namely almonds, hazelnuts, walnuts, cashews, pecan nuts, Brazil nuts, pistachio nuts, macadamia (or Queensland) nuts; Celery (including celeriac); Mustard; Sesame; Sulphur dioxide/sulphites, where added and at a level above $10 \mathrm{mg} / \mathrm{kg}$ or $10 \mathrm{mg} / \mathrm{L}$ in the finished product. This can be used as a preservative in dried fruit; Lupin, which includes lupin seeds and flour and can be found in types of bread, pastries and pasta; Molluscs like, mussels, whelks, oysters, snails and squid.

Allergenic foods are listed in Annex II to Regulation [6] no. 1169/2011. Informing the consumers of the occurrence of allergens in food means a written communication on all the allergens present in each specific food, meal and drink. Allergens must be presented with the word "contains," followed by the actual list of names of allergenic ingredients (unless the information about allergens is presented through a complete composition of the meal with the allergens highlighted).

According to the draft proposed to the Food Chamber of the Czech Republic, consumers must be provided information on allergens in writing and in the following way:

a) posted in a visible place (a list of prepared meals, 
along with information about the allergens they contain - written information indicating the allergens contained in individual dishes),

b) presented directly in the menu,

c) presented in writing upon personal request. It must be visibly and clearly communicated that information on allergens can be received after asking (e.g., "Information about allergens contained in meals is available upon request", etc.),

d) when ordering food for delivery or to go (e.g., ordering food via the Internet) the consumer must be informed of the allergens while the order is being made (e.g., via the website) and the information about allergens the food contains must be available even when the food is collected.

The principle of informing the consumer before his decision on the selection of meals drinks or food does not apply to sales through vending machines or automated commercial premises [5]. Another issue on which we focus our empirical research is that of pupils' diets in school canteens.

\section{Material and Methodology}

The investigation, conducted during January and February of 2015, was carried out through a random analysis of school canteens in Prague and the information provided on the possible occurrence of allergens in foods being served there. Another method used in this research was a form of Mystery Shopping, which was conducted by pupils in the canteens at the schools in question in Prague. Students were instructed on the appropriate methods for posing questions regarding the occurrence of allergens in various food offered. Another method used was a questionnaire survey, which was completed by 450 respondents from among the parents of the pupils. This survey was not focused on satisfaction with the quality of food served, but rather on the level of awareness of the potential presence of allergens in the school meals served. The final method employed was an examination in select educational institutions, which for reasons of time were located in the area of Prague 8, on the range of goods which are sold in school cafeterias as additional sales. This research was conducted through sensory comparisons of the food and beverages offered with a focus on nutritional values, awareness of the possible occurrence of allergens in these foods, on the suitability of the food offered, and the price.

\section{Results and Discussion}

$88 \%$ of randomly selected and examined school canteens offered information on their websites about the possible occurrence of allergens in meals served in their facilities. These educational institutions also submitted weekly menus, containing a warning in the form of a numeric code, on the presence of allergens in order to meet the need for notification of the occurrence of allergens in foods under European Parliament and Council Regulation [5] no. $1169 / 2011$ on the provision of food information to consumers, which came into force in the Czech Republic December 13, 2014. $7 \%$ of the surveyed school canteens did not provide information about the possible presence of allergens in food.

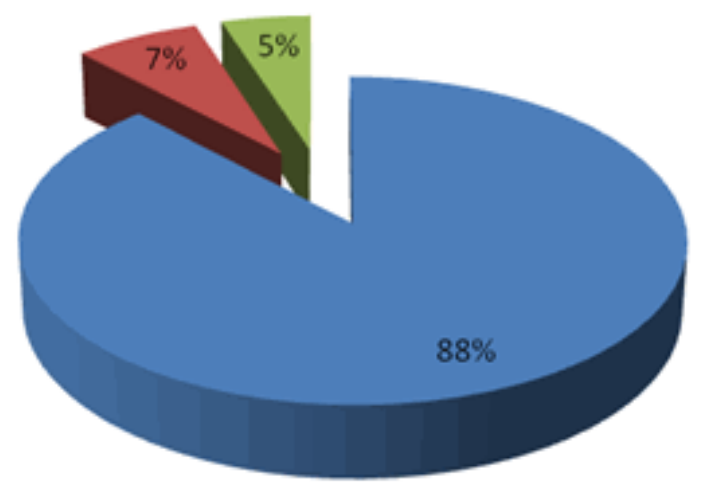

These school canteens appropriately informed about the occurrence of allergens in foods

- These school canteens did not provide information about the possibility of the occurrence of allergens in food

E These school canteens informed about the possible occurrence of allergens in food, but with the addition that was not possible to solved individuals student problems with health problems

Figure 1. School canteens 
In this case, we were unable to determine why these school facilities "failed" to disclose the requested information. $5 \%$ of the surveyed school cafeterias also provided information on their websites on the possible occurrence of allergens, as well as featured allergen content on the menu, but with the subsequent disclaimer that special care cannot be given to individuals (diners) who have such medical restrictions [9]. Likewise, these school facilities deny any responsibility for cases where children with dietary problems are using the school canteen and therefore require specially modified foods, even though the schools have this authority and the school is asked by parents about special diets for these cases.

The first issue that our research focused on was the level of awareness among the school canteen employees of the possible occurrence of allergens in food. In this case it was the kitchen staff that comes into contact with the children or "customers". For this research, we used the children of our acquaintances, and about 20 'second tier' primary school pupils, aged 12-14 years, who were able to formulate the required queries to the canteen staff regarding allergens in the food, agreed to participate in this Mystery shopping.

The second research goal that we set in accordance with the empirical investigation was met through a questionnaire survey with a focus on awareness of the possible allergens in food served in school canteens. As already mentioned, 450 respondents from among the parents participated in this empirical investigation. The questionnaire comprised 7 clearly formulated questions, was conducted during the month of January and was anonymous. For reasons of time and to ensure a sufficient number of respondents, 10 students from the Institute of Hospitality Management in Prague 8 acted as the interviewers for this part of the investigation. The interviewers were selected from among students whose residence is in the city of Prague and who live in the various Prague districts, since it was assumed that "historically" they may have some ties to their place of residence (school, family ties, friends etc.), and thus these empirical inquiries could be carried out smoothly. This step proved to be correct in view of the time schedule, which was designed for a period of 3 weeks with the research being completed before the spring break.

The third and final part of our empirical research addressed the issue of additional sales on school grounds and was conducted in 15 selected schools within the Prague 8 district. These additional sales are organized largely by external companies, which rent a booth or a room, on the school premises where they offer an assortment of food during the morning or afternoon snack time and in some cases offer a substitute for the midday meals for those who do not choose a meal from the menu in the canteen. First, the composition of the range of food on offer was observed from a sensory perspective. Then a trial purchase was made in these facilities, and the nutritional value of the products was evaluated. Last but not least, prices were compared in these school facilities

\section{Research Comments}

The resulting findings of the survey showed that $65 \%$ of the respondents were satisfied both with the quality of food served and with the awareness of the possible occurrence of allergens in the prepared foods offered in the school canteens. $29 \%$ of respondents commented negatively on the questions. It follows that these respondents were not satisfied with the information available on the occurrence of allergens in the food served in the school canteens. $6 \%$ of respondents expressed a lack of interest in this issue.

The findings of the research on school canteen staff awareness regarding the occurrence of allergens in the meals served showed an overall positive result. In this case, we instructed these helpers to lay simple and direct questions to the staff on the presence of gluten, eggs and milk. The students (pupils) were instructed to make a small tick mark in answer to the questions, which were subsequently evaluated. $90 \%$ of surveyed employees could explain to "the child customer" which meals contained allergens without having to look at the information table on allergens in food. On the other hand, for the $10 \%$ of respondents (kitchen staff) who failed to respond appropriately to the clearly targeted questions about the occurrence of specified allergens, we found knowledge gaps concerning the subject matter.

The findings of the investigation into the additional food sales on the school premises showed that in 12 facilities offering additional sales to primary school pupils, a totally inappropriate assortment of goods was offered. In these establishments the goods included: cola, bagels, biscuits and different kinds of candy, sugary sodas, various pastries, chips and various other snacks [5]. Only 3 facilities providing this type of sales did relatively well in the range of food offered, which unlike the other 12 facilities, limited this type of snack and offered foods that could be considered of a better category and were not only less expensive, but also better nutritionally and health wise. These 3 facilities offered various salads, fruits and mineral water without flavor. The worst finding was the price for the offered range of foods. Price levels reached the same as the non-stop convenience stores operated by Vietnamese retailers, which is significantly more expensive than other small retail shops. In one facility we even found out that the dealer offers the primary school pupils the opportunity to use euros for purchases using the exchange rate of 26.70 / 1 EUR, which according to the legal specifications is a violation of the law. The opportunity to make purchases using this currency is also not in accordance with the regulations on currency exchange activity, because this school does not have the authority to carry out foreign exchange services. 


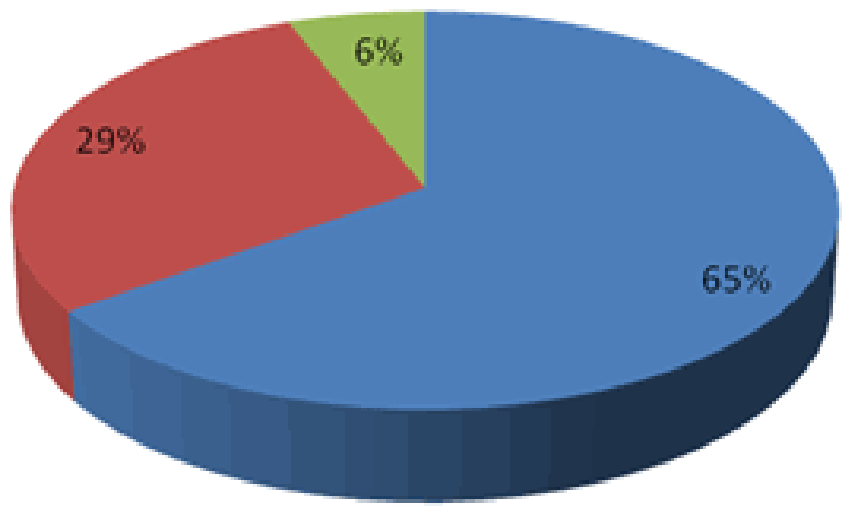

= Yes, we are satisfied with the information regarding the occurrence of allergens in food

No, we are not satisfied with the information available on the occurrence of allergens in food

= This problem does not concern us. We will not handle it.

Figure 2. Satisfaction with the quality of food

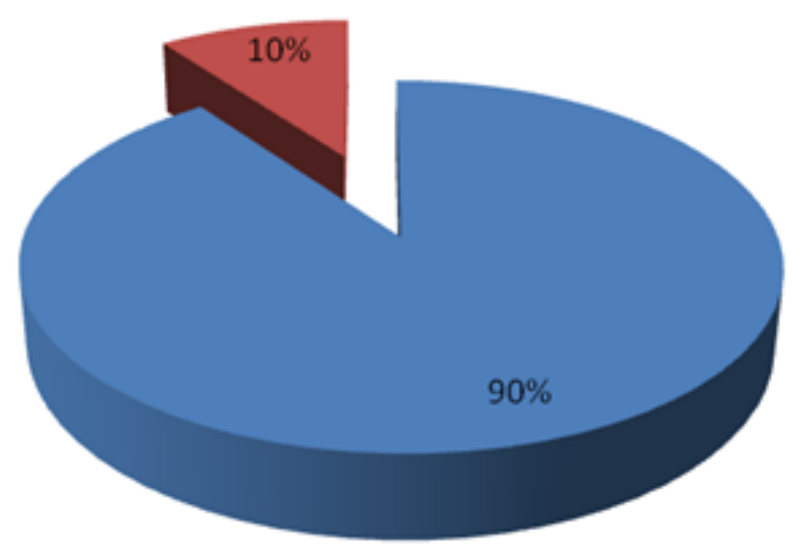

Employees of the school canteen were able informed about the possibility of the occurrence of allergens in foods.

- The staff of the school canteen failed to informed about the possibility of the occurrence of allergens in foods.

Figure 3. The staff of school canteens and their capacity to provide information about allergens.

\section{Conclusions}

Pursuant to Regulations of the European Parliament and Council Regulation [5] no. 1169/2011 dated 25. 10. 2011 on the provision of food information to consumers, which came into force in the Czech Republic, 12.13.2014, and school canteens, are obligated to inform consumers of food allergenic ingredients in prepared foods, but according to the statement of respondents in this research, some disregarded the hypersensitivity of individual diners. According to the statements of respondents with this problem, each consumer must guard against this problem themselves. Preparing meals in school canteens brings with it many risks. Each school canteen manager must reckon with it and consider whether to take on this risk [7]. Great responsibility - that is the main reason why some school cafeterias are afraid to accept special diets and it makes great demands on staff as well, both in terms of time consumption, and also regarding expertise. Workers need to know all the technology regarding the preparation of special diet foods, which are 
suitable for that particular diet and which are not. Unfortunately, in the school canteens where our research was conducted, such professionally trained staffs are lacking [8]. The growing number of parents of children with celiac's disease who are asking for help ensuring food for this special diet should get school canteen operators to think more about how to feed children with this problem. In our analysis of the canteen menus, we found that at least one meal a day from the three to five offered could be consumed by someone with celiac's disease, but it depends on the consumer's or his/her parent's choice [7]. According to the Supreme Administrative Court 2, Aps. 3/2010 - 112, the right to public school meals is a subjective right, which is decided by the Director of the school or school facility under $\S 164$ paragraph 1 point. a) Act no. 561/2004 Coll., on preschool, primary, secondary, vocational and other education (Education Act). This, however, does not imply that the student has the legal right to directly receive food that goes beyond the nutrition standards and financial limits pursuant to Decree no. 107/2005 Coll., on school meals. However, on the advice of the Ministry of Health Ref.: 34059/2011, the school canteen may serve children / pupils / students meals prepared in the child's home. Implementation is the full responsibility of the operator of the catering services on the basis of a written agreement with the legal guardian of the child, under the conditions and in accordance with that opinion. These diners can be recognized in the statement of operations, 17-01, on school catering from 31.10.2014.

\section{REFERENCES}

[1] Pollmer, U., Hoicke, C., Grimm, H-U., Višs, co jišš? je jídlo jed? (You know, what are you rating?: the food is poison?), 2006, $1^{\text {st }}$ ed., Fontána, Olomouc, 272 p., ISBN: 8073360926

[2] Zíková, V. 2011. Jak zbavit dite atopickeho ekzemu upravou stravy deti do tri let. [cit. 2015-04-02] Available at: http://www.proalergiky.cz/magazin/specialy/jak-zbavit-diteatopickeho-ekzemu-upravou-stravy-deti-do-tri-let

[3] Collection of laws of the Czech Republic 2008, the full text of Act No. 561/2004 Coll. on pre-school, primary, secondary, higher vocational and other education (the Education Act), (Sbírka zákonů ČR 2008, Úplné znění zákona č. 561/2004 Sb., o předškolním, základním, středním, vyšším odborném a jiném vzdělávání (školský zákon).

[4] Ministerstvo zdravotnictví podle § 121 odst. 2 školského zákona: Předpis č. 107/2005 Sb. (Vyhláška o školním stravování, platnost od 8/3/2005. (Decree no. 107/2005 Coll., on school meals. However, on the advice of the Ministry of Health Ref.: 34059/2011, the school canteen may serve children / pupils).

[5] Potravinářská komora ČR. Nařízení Evropského parlamentu a Rady (EU) č. 1169/2011 ze dne 25. 10. 2011 o poskytování informací o potravinách spotřebitelům. (The food Chamber of the CZECH REPUBLIC. European Parliament and Council Regulation no 1169/2011 from 25 June).

[6] Steinmann, M. A. 1993. Rádce rodičů dětí s alergiemi a astmatem (Parent's Guide to Allergies and Asthma), $1^{\text {st }}$ ed., S Aktuell, Sfinga, Bratislava, Ostrava, 225 p., ISBN: 808559708X

[7] Bidat, E., Loigerot, Ch., Paulasová, E. 2005. Alergie u dětí (Children Allergies), $1^{\text {st }}$ ed., Portál / Rádci pro rodiče a vychovatele, Praha, 148 p., ISBN: 8071789364

[8] Lužná, D. 2010. Vařime pro děti podle makrobiotických zásad (Cook for children according to the macrobiotic principles), Anag, Praha, 280 p., ISBN 978-80-7263-602-0

[9] Šebestíková, T. 2012. Vařime dětem (We cook for children), Studio Trnka, 64 p., ISBN 978-80-87209-42-4.

[10] Zákon o závodním stravování - Stravování zaměstnanců příspěvkových organizací zrrízených obcí či krajem se řídí vyhláškou MF ČR č. 84/2005 Sb., o nákladech na závodní stravování a jejich úhradě $\mathrm{v}$ prríspěvkových organizacích zrrízených územními samosprávnými celky. (The Labour Code. Law no. 84/2005 Coll., Legislation corporate catering staff allowance organizations established by local authorities). 